\title{
DESA TRUNYAN: MASYARAKAT DAN KEBUDAYAANNYA \\ oleh
}

I Gede Febby Pramitha Yasa dan I Putu Putrayana Wardana

Feby_guanteng@gmail.com, putra.yana@undiksha.ac.id

Pendahuluan

Bali merupakan sebuah pulau yang berada di wilayah Indonesia. Bali merupakan destinasi wisata terbaik yang berada di Indonesia. Selain keindahan alamnya yang mempesona bali juga terkenal dengan budayanya serta tradisinya yang khas dan tidak dimiliki oleh daerah lainnya.

Salah satu tradisi yang sekaligus menjadi destinasi wisata terbaik yang berada di Bali adalah desa Trunyan. Desa yang berada di kecamatan Kintamani ini mampu memikat wisatawan domestik maupun internasional dengan keunikan budayanya dan tradisinya.

Keunikan budaya serta tradisi yang berada di desa terunyan ini sekaligus menjadi salah satu berkah bagi masyarakat di desa Terunyan karena berkat tradisinya yang unik ini menjadikan desa terunyan sebagai salah satu desa wisata terbaik yang berada di bali.

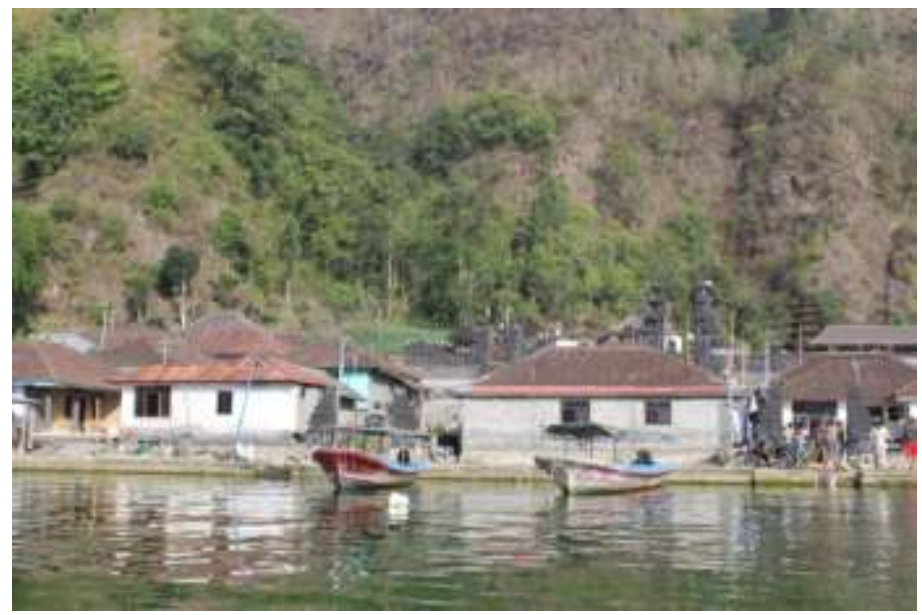

Agung ,2017,Desa Trunyan,28 November 2017 
Dari hal diatas juga terdapatnya rumusan masalah yaitu (1)Bagaimanakah tradisi masyarakat di desa Terunyan?(2) Bagaimanakah cara masyarakat setempat melestarikan tradisinya?

\section{Tradisi Desa Trunyan}

1. Proses Pemakaman Jenasah

- Sejarah

Menurut legenda, pohon Taru Menyan ini dulu baunya sampai tercium hingga Keraton Solo yang jaraknya beratu-ratus kilometer dari Bali. Karena bau wangi itulah, empat bersaudara dari Keraton Solo mencoba untuk mencari sumbernya. Hingga empat bersaudara yang terdiri dari satu perempuan dan tiga anak laki-laki itu rela mengarungi daratan hingga ganasnya lautan untuk bisa menemukan sumber bau tersebut. Pada akhirnya mereka sampai pada Desa Trunyan dan menemukan sumber bau yang sangat harum tersebut. Dimana bau yang harum itu bersumber dari pohon besar yang bernama Taru Menyan.

Namun setelah menemukan sumber bau wangi tersebut, kakak sulung dari empat bersaudara itu justru jatuh cinta pada seorang Dewi yang menjadi penunggu pohon Taru Menyan. Tak berselang lama, kakak sulung tersebut akhirnya menikahi sang Dewi. Setelah menikah, hadirlah sebuah kerajaan kecil yang letaknya persis ditepi danau Batur, tempat pohon itu tumbuh. Meskipun sang Dewi telah menikah, namun pohon Taru Menyan masih terus mengeluarkan bau yang sangat harum. Karena takut diserang oleh kerajaan lain karena bau semerbak dari pohon Taru Menyan, maka sang Raja memerintahkan penduduk kerajaan menghilangkan bau wangi dengan cara meletakkan beberapa jenazah tepat dibawah pohon tersebut. Cara itu ternyata berhasil, karena pohon Taru Menyan sudah tak mengeluarkan bau wangi dan jenazah yang ada dibawah pohon itu juga tak mengeluarkan bau busuk. Sampai saat ini masyarakat Desa Trunyan masih melakukan pemakaman dengan cara meletakkan jenazah begitu saja dibawah pohon Taru Menyan. Namun yang dimakamkan di tempat tersebut hanyal orang yang berhati mulia.

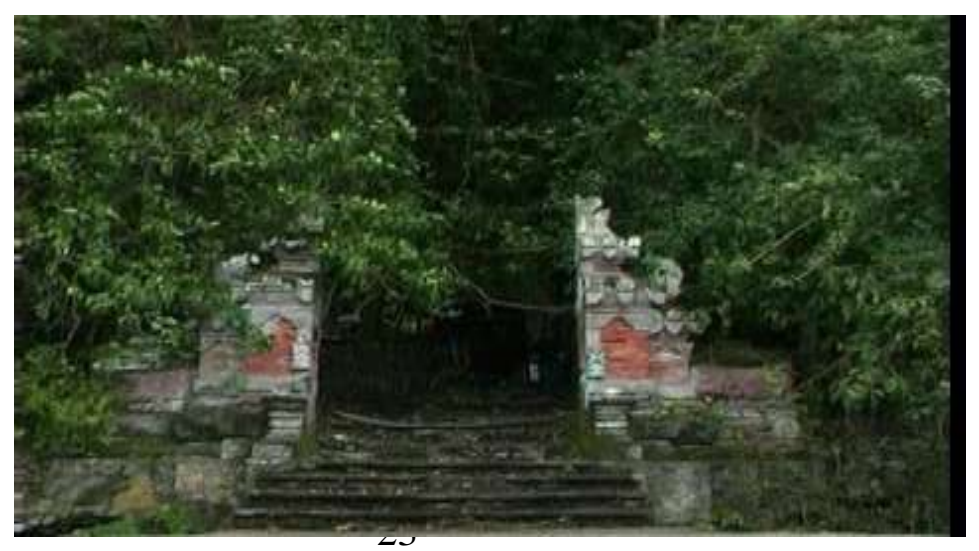


- Proses Pemakaman

Di proses pemakaman juga terdapat bagian-bagian tertentu yaitu pemakaman sema wayah, sema bantas, sema nguda.

Penjelasan :

a. Sema Wayah digunakan secara spesifik untuk mayat yang dimakamkan secara mepasah.

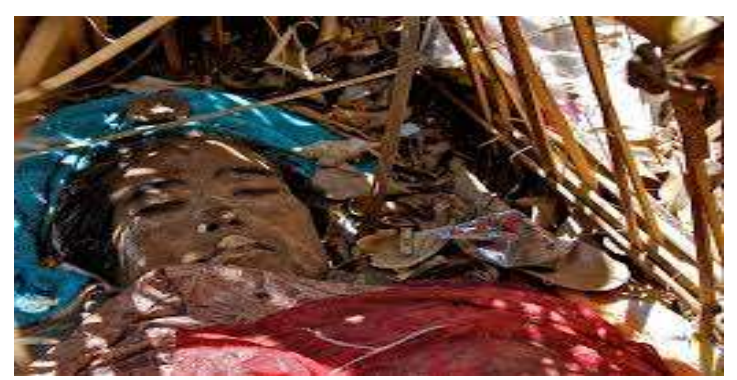

Agung ,2017,Desa Trunyan,28 November 2017

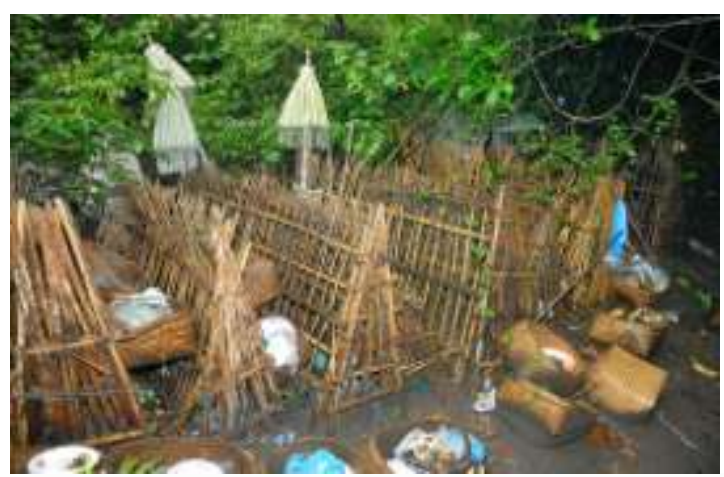

Agung ,2017,Desa Trunyan,28 November 2017

b. Sema bantas dipakai untuk jenis pemakaman khusus untuk mayat yang dikubur.

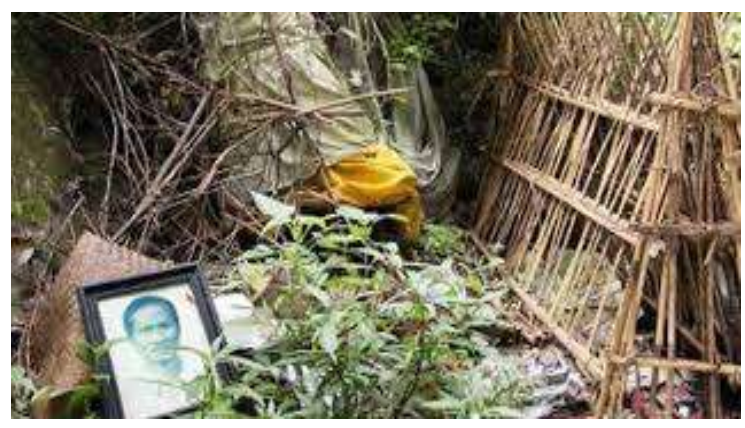




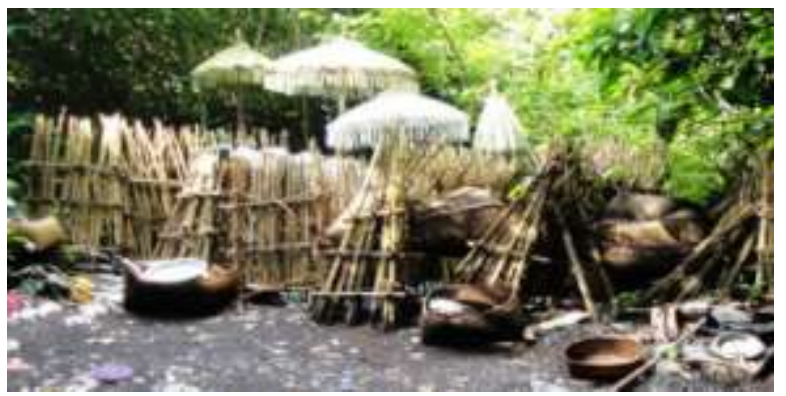

Agung ,2017,Desa Trunyan,28 November 2017

c. Sema Nguda merupakan lokasi pemakaman yang bisa digunakan baik untuk mayat mepasah ataupun mayat yang dikubur.

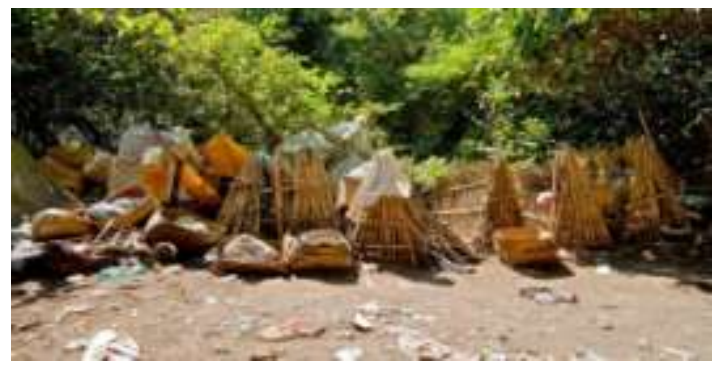

Agung ,2017,Desa Trunyan,28 November 2017

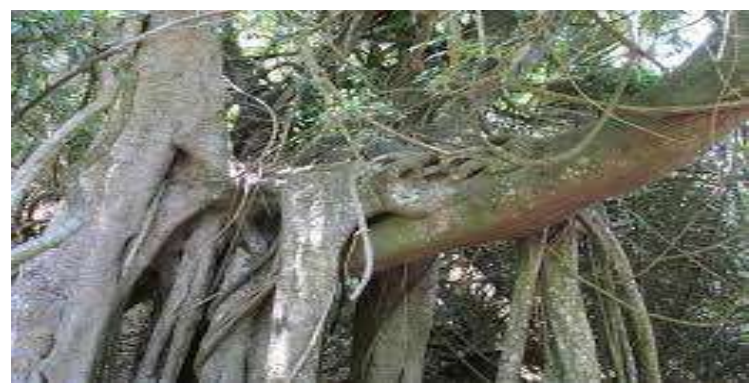

Agung ,2017,Desa Trunyan,28 November 2017

Mayat yang dikubur biasanya adalah mereka yang meninggal karena penyakit. Selain itu, mayat yang meninggal karena kecelakaan, anak kecil yang giginya belum tanggal, meninggal secara tidak wajar, dibunuh ataupun merupakan mayat orang bunuh diri dimakamkan secara dikubur. 
Sementara mayat mepasah adalah untuk masyarakat Desa Trunyan Bali yang meninggal setelah berumah tangga. Para bujangan dan anak kecil yang giginya telah tanggal juga masuk dalam kategori mayat mepasah. Dan meski ditelantarkan begitu saja, mayat mepasah pun ternyata tidak berbau busuk, malah wangi. Hal ini karena keberadaan pohon taru menyan yang mempunyai fungsi untuk menghilangkan bau bangkai mayat mepasah.

Kebudayaan Desa Trunyan

\section{- Barong Berutuk}

Barong brutuk adalah Barong yang terpopuler di Bali selain Barong tersebut sakral hanya dipentaskan di Pura atau tempat suci, juga dipentaskan untuk keperluan hiburan. Ada beberapa jenis Barong yang ada di Bali diantaranya selain Barong Brutuk dan Ket ada Barong Landung, Bangkal, Asu, Blasblasan, Gajah dan Macan. Diantara semuanya Barong Brutuk adalah yang paling unik dan hanya ada di satu tempat yaitu Desa Trunyan, Kecamatan Kintamani, Bangli.Barong Brutuk tersebut, ditampilkan setiap dua tahun sekali pada saat piodalan atau upacara Ngusaba Kapat di Pura Pancering Jagat di desa Trunyan. Menurut Kalender Isaka Piodalan di Pura Pancering jagat jatuh pada hari Purnamaning Kapat. Pada saat piodalan atau Ngusaba Kapat tersebut dikenal dengan istilah Kapat Lanang dan Kapat Wadon. Dan bertepatan saat Ngusaba Kapat Lanang, Barong Brutuk tersebut dipentaskan, ditampilkan oleh para teruna atau para remaja pria. Sedangkan Ngusaba pada tahun berikutnya yang dikenal dengan Kapat Wadon adalah kegiatan remaja puteri yang aktif untuk mengisi kegiatan saat upacara piodalan di pura dengan cara menenun kain suci.Begitu unik dan menarik Barong Brutuk di desa Tenganan, karena kesakralannya Barong Brutuk tidak dipentaskan di sembarang tempat ataupun sembarang waktu. Menurut kepercayaan masyarakat setempat Barong Brutuk tersebut adalah wujud rencang atau unen-unen (anak buah) dari leluhur masyarakat setempat yaitu Ratu Sakti Pancering Jagat dan Ratu Ayu Dalem Pingit Dasar. Uniknya lagi pementasan Barong Brutuk tidak diiringi oleh gamelan seperti pementasan tari barong lainnya, dalam pementasan tidak terlihat adanya gerak tari. Begitu juga pakaian yang digunakan dari kumpulan daun kraras atau daun pisang yang sudah kering.Tentu pakaian yang digunakan oleh Barong Brutuk tersebut jauh dari kemewahan apalagi gemerlap. Daun-daun pisang kering (kraras) tersebut konon hanya diperbolehkan diambil dari desa Pinggan. Daun pisang kering tersebut dirajut menggunakan tali dari kulit daun pisang juga, dibentuk seperti rok digantungkan pada leher, bahu dan pinggang penarinya yang cukup tebal sampai 3 lapis rangkaian daun kraras, serta celana dalam penarinya terbuat dari kelopak kering pohon pisang, dan memakai topeng, serta membawa sebuah cambuk berjalan mengelilingi halaman pura.Topeng-topeng yang 
dikenakan oleh Barong Brutuk memiliki ciri khas dan karakter masing-masing berbeda, ada topeng yang berwajah tegas dan kuat sebagai tokoh raja ada juga yang lebih feminim sebagai tokoh ratu, ada topeng sebagai tokoh patih dan kakak ratu, serta banyak lagi lainnya. Bahkan konon jumlah topeng tersebut berubahrubah setiap harinya terkadang berjumlah 21 terkadang 23 dan bahkan bisa 19 topeng, jadi berarapapun jumlah topeng yang ada di penyimpanan perhari itu, semua akan dipakai dan ditarikan oleh masing-masing pemain. Namun sampai saat ini belum diketahui secara pasti siapa pembuat topeng tersebut, karena

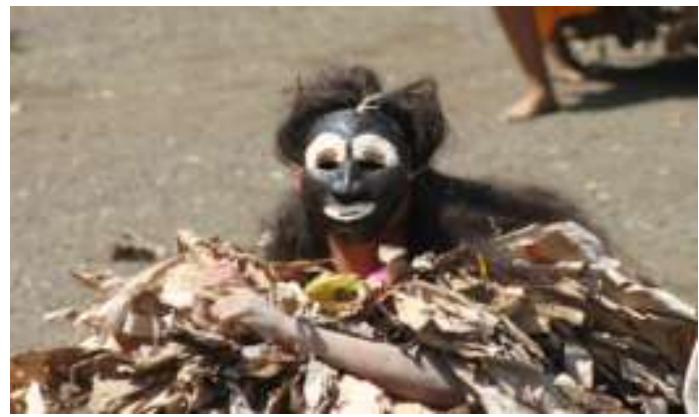

mereka menemukan sudah ada turun-temurun.Pada saat keliling pura, Barong Brutuk dengan cambuknya akan dilecutkan ke penonton, lecutan cambuk yang mengenai tubuh tersebut dipercaya sebagai tamba (obat) yang bisa menyembukan penyakit. Bagitu juga dengan pakaian dari potongan-potongan daun kraras (daun pisang kering) tersebut dipercaya membawa berkah dan keselamatan. Bahkan juga Barong Brutuk melemparkan buah-buhan dari persembahan ke para penonton yang berarti memberikan kesejahteraan dan kemakmuran.Menjelang pementasan Barong Brutuk di pura Pancering Jagat desa Trunyan, para pemaian yang terdiri dari para teruna (para remaja) desa, menjalani ritual penting, mereka selama 42 hari disucikan atau dikarantina di sekitar Pura Pancering Jagat dekat patung Bhatara Datonta atau Ratu Pancering Jagat, mempelajari tembangtembang kuno dan membersihkan areal pura dan juga mereka pantang berhubungan dengan wanita, serta mengunpulkan daun-daun pisang (kraras) dari desa Pinggan.Sebuah budaya dan tradisi unik di desa Trunyan ini memang patut anda nikmati, karena hanya dipentaskan hari tertenu dan hanya di desa ini saja. Untuk menuju ke desa Trunyan anda harus sewa perahu dari dermaga Kedisan atau Toyabungkah untuk menyebrangi danau Batur.

yoga ,2015,Desa Trunyan,28 November 2017

yoga ,2015,Desa Trunyan,28 November 2017

\section{Kesimpulan}

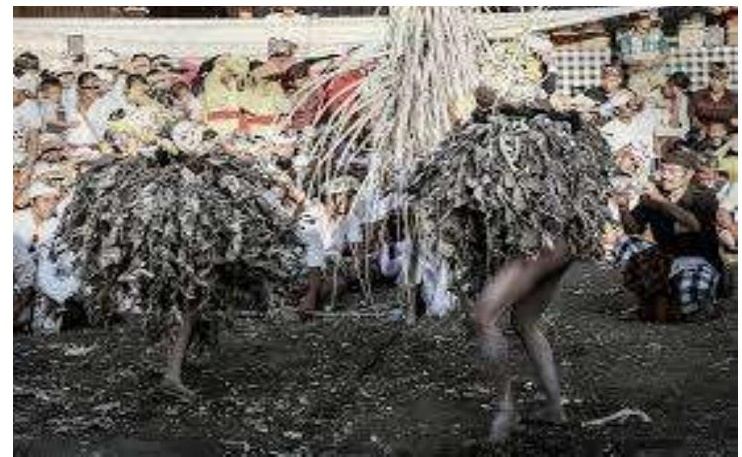


Desa Trunyan memiliki kebudayaan maupun tradisi sangat unik yang hanya dimiliki oleh desa Trunyan saja , bahkan keunikan yang dimiliki desa tersebut tidak hanya terkenal di bali maupun Indonesia saja yaitu sudah terkenal secara internasional dan sudah banyak wisatawan yang sering berkunjung ke wisata tersebut.

.Kebudayaan desa Trunyan (barong brutuk) . Tersedia pada: http://www.balitoursclub.net/barong-brutuk-trunyan/ (diunduh pada 17-12-2017

Proses pemakaman di desa Trunyan. Tersedia pada: http://wowasiknya.com/desatrunyan/(diunduh pada 12-12-2017

Asal usul desa Trunyan. Tersedia pada http://www.terseram.com/2016/08/asal-usul-desatrunyan-bali.html .(diunduh pada 12-12-2017 